\title{
Autoimmune hemolytic anemia in HCV/HIV coinfected patients during treatment with pegylated alpha-2a interferon plus ribavirin
}

\author{
Anemia hemolítica auto-imune durante o tratamento da hepatite crônica \\ com interferon peguilado alfa $2 a$ e ribavirina, \\ em pacientes com co-infecção HCV/HIV
}

\author{
Fernando Crivelenti Vilar ${ }^{1}$, Gleusa de Castro ${ }^{1}$, Maria Janete Moya ${ }^{1}$, \\ Ana de Lourdes Candolo Martinelli², Gil Cunha De Santis ${ }^{3}$, \\ Ana Paula Costa Nunes da Cunha Cozac ${ }^{3}$ e José Fernando de Castro Figueiredo ${ }^{1}$
}

\begin{abstract}
Two cases of autoimmune hemolytic anemia that occurred during the treatment of chronic hepatitis $C$ with pegylated alpha-2a interferon and ribavirin, in HIV coinfected patients, are presented and described. The late occurrence (after six months of therapy) of this severe hemolytic anemia leads to the recommendation that hemoglobin levels should be monitored throughout the treatment period, even among patients who presented stable hemoglobin levels in the preceding months.
\end{abstract}

Key-words: Hemolytic anemia. Treatment. Hepatitis C. Pegylated alpha-2a interferon. HIV/AIDS.

\section{RESUMO}

São apresentados e discutidos dois casos de anemia hemolítica auto-imune que ocorreram durante o tratamento da bepatite crônica pelo vírus $C$, com interferon peguilado alfa 2 a e ribavirina, em pacientes co-infectados pelo HIV. A ocorrência de anemia hemolítica grave em etapa tardia, após o sexto mês da terapêutica, recomenda que o controle dos níveis de hemoglobina deva ser feito durante todo o período do tratamento , mesmo nos pacientes que apresentam níveis estáveis de hemoglobina nos meses precedentes.

Palavras-chaves: Anemia hemolítica. Tratamento. Hepatite C. Interferon peguilado alfa 2a. HIV/AIDS.

Coinfection with the hepatitis $\mathrm{C}$ virus (HCV) and human immunodeficiency virus (HIV) is common and its prevalence varies according to the epidemiological conditions of the region in which the viruses are transmitted. Faster progression of fibrosis in coinfected patients ${ }^{2}$, in addition to longer survival due to the use of highly active antiretroviral therapy (HAART $)^{5}$, has increased the frequency of chronic complications of hepatitis $\mathrm{C}$ in these patients ${ }^{11}$. Thus, if not contraindicated, hepatitis $\mathrm{C}$ treatment in HCV/HIV coinfected patients has been proposed ${ }^{3}$.

The current goal in chronic hepatitis $\mathrm{C}$ therapy with pegylated interferon (Peg-INF) and ribavirin (RBV) in HCV/HIV coinfected patients is to achieve a sustained virological response (SVR) ${ }^{12}$. Use of
RBV has been considered responsible for the great majority of anemia cases that are associated with treatment of chronic hepatitis C. Different mechanisms have been suggested in order to explain the anemia, such as oxidative stress on erythrocyte membranes, mitochondrial toxicity and downregulation of erythropoietin receptors .

On the other hand, although less frequently, interferon may aggravate or even be responsible for the anemia seen in hepatitis C-treated patients. In such cases, the anemia could be due to direct drug medullary toxicity or autoimmunity induction ${ }^{710}$.

The present report discusses aspects of the autoimmune hemolytic anemia that occurred in two HCV/HIV coinfected patients who were treated with Peg-IFN alpha-2a and RBV.

\footnotetext{
1. Division of Infectious and Tropical Diseases, Department of Internal Medicine, Faculty of Medicine of Ribeirão Preto, University of São Paulo, Ribeirão Preto, SP. 2. Division of Gastroenterology, Department of Internal Medicine, Faculty of Medicine of Ribeirão Preto, University of São Paulo, SP, Ribeirão Preto, SP. 3. Hemocentro Foundation, Ribeirão Preto, SP.

Address to: Dr. José Fernando de Castro Figueiredo. Divisão de Moléstias Infecciosas e Tropicais/DCM/FMRP/USP. Av. Bandeirantes 3900, 14048-190 Ribeirão Preto, SP. Tel: $55163602-2468$

e-mail: jfcfigue@fmrp.usp.br

Recebido para publicação em: 14/06/2007

Aceito em 11/10/2007
} 


\section{CASE REPORTS}

Case 1. A 51-year-old HIV-infected male patient who was regularly using zidovudine, lamivudine and nevirapine presented $\mathrm{a} \mathrm{CD}_{4}^{+}$lymphocyte count of 734 cells/ $/ \mathrm{mm}^{3}$ and HIV viremia of less than 50 copies/ $\mathrm{mm}^{3}$. The patient was also HCV-infected (positive HCV RNA; genotype $1 \mathrm{~b}$; HCV viremia of $311,235 \mathrm{UI} / \mathrm{ml}$ ). A hepatic biopsy showed histological activity index (HAI) of 10 and moderate fibrosis (F2) ${ }^{6}$.

Treatment with Peg-IFN alpha-2a (F. Hoffmann La Roche, Basel, Switzerland; 180 $\mu \mathrm{g} /$ week) and RBV (Biolunis Farmacêutica Ltda, São Paulo, Brazil; 1,250 mg/day) was started. At this time, the routine hematological test results were: hemoglobin $(\mathrm{Hb})=14 \mathrm{~g} / \mathrm{dl}$; red blood cells $(\mathrm{RBC})=3.96 \times 10^{6} / \mathrm{mm}^{3}$; hematocrit $(\mathrm{Ht})=48 \%$; leukocytes $=4,400 / \mathrm{mm}^{3}$ and platelets $=145,000 / \mathrm{mm}^{3}$. Four weeks after the beginning of the treatment, $\mathrm{Hb}$ had decreased to $12 \mathrm{~g} / \mathrm{dl}$, without changes in the other blood parameters. After eight weeks, $\mathrm{Hb}$ was $10.8 \mathrm{~g} / \mathrm{dl}$, anemia secondary to $\mathrm{RBV}$ was suspected and its dosage was reduced to $500 \mathrm{mg} /$ day. In the $12^{\text {th }}$ week of treatment, the $\mathrm{Hb}$ level had increased to $11.1 \mathrm{~g} / \mathrm{dl}$. The patient was started on recombinant human erythropoietin, $6,000 \mathrm{U}$ three times a week and the RBV dosage was increased to $1,000 \mathrm{mg} /$ day. At this time, HCV-RNA was negative. In the $14^{\text {th }}$ week, $\mathrm{Hb}$ had again decreased, to $10.6 \mathrm{~g} / \mathrm{dl}$, and the treatment was maintained. Five weeks later, $\mathrm{Hb}$ was $8.4 \mathrm{~g} / \mathrm{dl}$, the patient was still asymptomatic. The erythropoietin dosage was increased to $8,000 \mathrm{U}$ three times a week and the RBV dosage was reduced again to $500 \mathrm{mg} /$ day. However, in the $23^{\text {rd }}$ week, the patient presented dyspnea and dizziness and his $\mathrm{Hb}$ level was $6.5 \mathrm{~g} / \mathrm{dl}$. At this point, the use of Peg-IFN and RBV was discontinued, while treatment with erythropoietin and highly active antiretroviral therapy (HAART) was maintained. In the $24^{\text {th }}$ week, 10 days after stopping hepatitis $\mathrm{C}$ treatment, $\mathrm{Hb}$ had decreased to $4.5 \mathrm{mg} / \mathrm{dl}$ and the patient was admitted to hospital. The direct antiglobulin test (DAT) was strongly positive (4+ $\operatorname{IgG}$ and $\mathrm{C} 3 \mathrm{~d})$ and the eluate reacted with all the panel cells $(3+$ in low-ion strength solution and $4+$ for papain-treated erythrocytes). The serum was also reactive to all the panel cells $(2+$ in low-ion strength solution and $4+$ for papaintreated erythrocytes) including autologous erythrocytes (positive autocontrol). The lactic dehydrogenase concentration was 3,615U/ (upper limit: 450U/1) and the reticulocyte count was 16.1\%. Cobalamin and folic acid plasma levels were normal. Based on the suggested diagnosis of drug-induced autoimmune hemolytic anemia, the patient was treated with prednisone $1 \mathrm{mg} / \mathrm{kg} / \mathrm{day}$, and the $\mathrm{Hb}$ levels progressively improved. Six months later, now no longer on corticosteroid therapy, the direct antiglobulin test was still positive (IgG and C3d).

Case 2. A 46-year-old HIV-infected male patient who was regularly using zidovudine, lamivudine and indinavir presented a $\mathrm{CD}_{4}^{+}$lymphocyte count of 639 cells $/ \mathrm{mm}^{3}$ and HIV viremia of less than 50 copies/ml. The patient was also HCV-infected (positive HCV RNA; genotype 3a) and a hepatic biopsy performed seven years earlier showed histological activity index (HAI) of 6 and mild fibrosis (F1) [8]. Treatment with interferon alpha-2a $(3,000,000 \mathrm{U}$ three times a week) and $\mathrm{RBV}(1,000 \mathrm{mg} /$ day $)$ was started, but after 24 weeks it was suspended since HCV RNA remained positive. A new hepatic biopsy was performed and showed HAI = 12 and moderate fibrosis (F2 $)^{6}$. Treatment with Peg-IFN alpha-2a (F. Hoffmann La Roche, Basel, Switzerland; 180 $\mathrm{g} /$ week) and RBV (Biolunis Farmacêutica Ltda, São Paulo, Brazil; 1,250mg/ day) was then restarted. At this time, the routine hematological tests were: $\mathrm{Hb}=13.4 \mathrm{~g} / \mathrm{dl} ; \mathrm{RBC}=3.37 \times 10^{6} / \mathrm{mm}^{3} ; \mathrm{Ht}=41.8 \%$; leukocytes $=5,700 / \mathrm{mm}^{3}$ and platelets $=185,000 / \mathrm{mm}^{3}$. Four weeks after the beginning of this treatment, $\mathrm{Hb}$ had decreased to $9.1 \mathrm{~g} / \mathrm{dl}$ without changes in the other blood parameters. The RBV dosage was reduced to $1,000 \mathrm{mg} / \mathrm{d}$ and the patient was started on recombinant human erythropoietin, 4,000U three times a week. In the $8^{\text {th }}$ week, $\mathrm{Hb}$ was $9.0 \mathrm{~g} / \mathrm{dl}$ and its level remained stable until the $24^{\text {th }}$ week when HCV-RNA was found to be negative. However, in the $26^{\text {th }}$ week, $\mathrm{Hb}$ had decreased to $7.3 \mathrm{~g} / \mathrm{dl}$ and recombinant human erythropoietin was raised to $10,000 \mathrm{U}$ three times a week. In the $28^{\text {th }}$ week, the level of $\mathrm{Hb}$ had decreased to $5.5 \mathrm{~g} / \mathrm{dl}$ and PegIFN and RBV were discontinued, while erythropoietin and HAART were maintained. One week later, the $\mathrm{Hb}$ level had decreased to $4.7 \mathrm{~g} / \mathrm{dl}$ and the patient was admitted to hospital. DAT was positive (3+ IgG and $\mathrm{C} 3 \mathrm{~d})$; the eluate was negative for irregular antibodies and the reticulocyte count was $1.2 \%$. The patient was transfused with two units of erythrocyte concentrate and, without corticosteroid therapy, there was a gradual increase in $\mathrm{Hb}$ levels. Four months later, the direct antiglobulin test was still weakly positive (IgG and C3d), but without any sign of hemolysis.

The general data on the patients are summarized in Table 1.

Table 1 - General data on patients with autoimmune bemolytic anemia.

\begin{tabular}{|c|c|c|}
\hline Variables & Case 1 & Case 2 \\
\hline Sex & male & male \\
\hline Age (years) & 51 & 46 \\
\hline \multicolumn{3}{|l|}{$\mathrm{CD}_{4}^{+}$lymphocytes at the beginning } \\
\hline of hepatitis $\mathrm{C}$ treatment & 734 cells $/ \mathrm{mm}^{3}$ & 639 cells $/ \mathrm{mm}^{3}$ \\
\hline \multicolumn{3}{|l|}{ HIV viral load at the beginning of } \\
\hline hepatitis C treatment & $<50$ copies $/ \mathrm{mm}^{3}$ & $<50$ copies $/ \mathrm{mm}^{3}$ \\
\hline \multicolumn{3}{|l|}{ HCV RNA (genotype) at: } \\
\hline beginning of hepatitis $\mathrm{C}$ treatment & positive (1b) & positive (3a) \\
\hline during hepatitis $\mathrm{C}$ treatment & negative & negative \\
\hline after discontinuation of treatment & positive & positive \\
\hline Hepatic biopsy & $\mathrm{HAI}=10 ; \mathrm{F}=2$ & $\mathrm{HAI}=12 ; \mathrm{F}=2$ \\
\hline \multicolumn{3}{|l|}{ Hepatitis C treatment: } \\
\hline Peg-IFN alpha-2a & $180 \mathrm{mg} /$ week & $180 \mathrm{mg} /$ week \\
\hline RBV & $1,250 \mathrm{mg} /$ day & $1,250 \mathrm{mg} /$ day \\
\hline \multicolumn{3}{|l|}{ Hemoglobin level at the beginning of } \\
\hline treatment & $14 \mathrm{~g} / \mathrm{dl}$ & $13.4 \mathrm{~g} / \mathrm{dl}$ \\
\hline Decrease (\%) in Hb level at the nadir & 70 & 65 \\
\hline Treatment week at the $\mathrm{Hb}$ nadir & $25^{\text {th }}$ & $29^{\text {th }}$ \\
\hline Direct antiglobulin test & positive $(4+)$ & positive $(3+)$ \\
\hline Lactic dehydrogenase & $3.615 \mathrm{U} / 1$ & $665 \mathrm{U} / 1$ \\
\hline Reticulocyte (\%) & 16.9 & 1.2 \\
\hline Time taken for Hb recovery (weeks) & 7 & 7 \\
\hline Total/direct bilirubin (highest value) & $1.18 / 1.01$ & $1.15 / 0.99$ \\
\hline Corticosteroid use & yes & no \\
\hline Red cell transfusion & no & yes \\
\hline
\end{tabular}




\section{DISCUSSION}

Anemia is an important side effect of the drugs used in hepatitis $\mathrm{C}$ treatment. $\mathrm{RBV}$ is the main drug responsible for such side effects, which are expected to produce a decrease of 1 to $3 \mathrm{~g} / \mathrm{dl}$ in $\mathrm{Hb}$ levels over the first eight weeks of treatment ${ }^{7}$. Thus, $\mathrm{RBV}$ dosages frequently need to be modified during the first eight weeks of treatment, because of anemia. Today, the treatment for chronic hepatitis $\mathrm{C}$ in HIV coinfected patients is a combination of Peg-IFN alpha-2a or $2 \mathrm{~b}$ and RBV, for a period of at least 48 weeks, independent of the HCV genotype ${ }^{12}$. In this context, severe anemia leading to drug withdrawal is uncommon ${ }^{2}$. Autoimmune drug-induced hemolytic anemia in chronic mono-HCV-infected patients has been reported ${ }^{40}$, as well as autoimmune hemolytic anemia associated with $\mathrm{HCV}^{8}$ or HIV infection?

In the case reports presented here, the two HIV/HCV coinfected patients developed autoimmune hemolytic anemia that was probably related to the use of Peg-IFN alpha-2a. It is worth noting that, in both cases, anemia occurred in two distinct phases. In the first phase, the $\mathrm{Hb}$ levels decreased during the first four weeks of treatment and stabilized at around $9 \mathrm{~g} / \mathrm{dl}$. They remained at that level up to the $20^{\text {th }}$ week, probably due to the action of $\mathrm{RBV}$ on the erythrocytes ${ }^{7}$. Thereafter, the Hb levels fell abruptly to below $5 \mathrm{~g} / \mathrm{dl}$ over a few weeks, even after drug withdrawal. This late anemia, with laboratory results indicative of autoimmune hemolysis, was probably secondary to the immunomodulatory action of Peg-IFN ${ }^{1}$ and may have been influenced by the HIV infection ${ }^{9}$. In one of the drug-induced classical hemolysis mechanisms, it is considered that the antibody recognizes the antigen complex on the erythrocyte-drug surface. In this situation, the eluate and antibody search will be negative, although the direct antiglobulin test is positive. In Case 1, however, both the eluate and antibodies were positive, probably due to concomitant and sometimes oscillating autoimmunity induced by the HIV disease. It is noteworthy that in both cases, the Hb levels increased over a short period of time (seven weeks) after discontinuation of treatment, even when the DAT was still positive. In addition, the observed occurrence of late anemia leads to the recommendation of frequent monitoring of $\mathrm{Hb}$ levels throughout the treatment, even among patients with stable hematological parameters during the first 20 weeks of therapy.

\section{REFERENCES}

1. Barbolla L, Paniagua C, Outeirino J, Prieto E, Sanchez Fayos J. Haemolytic anaemia to the alpha-interferon treatment: a proposed mechanism. Vox Sanguinis 65:156$157,1993$.

2. Benhamou Y, Bochet M, Di Martino, Charlotte F, Azra F, Coutelier A, Vidaud M, Bricaire F, Opolon P, Katlama C, Poynard C. Liver fibrosis progression in human immunodeficiency virus and hepatitis $\mathrm{C}$ virus co-infected patients. The Multivirc Group. Hepatology 30:1054-1058, 1999.

3. Brau N. Treatment of chronic hepatitis $\mathrm{C}$ in human immunodeficiency virus/ hepatitis $\mathrm{C}$ virus-coinfected patients in the era of pegylated interferon and ribavirin. Seminars in Liver Diseases 25:33-51, 2005.

4. Cauli C, Serra G, Chessa L, Balestrieri C, Scioscia R, Lai ME, Farci P. Severe autoimmune hemolytic anemia in a patient with chronic hepatitis $\mathrm{C}$ during treatment with peginterferon alfa-2a and ribavirin. Haematologica 91:33-34, 2006.

5. Hammer SM, Squires KE, Hughes MD, Grimer GM, Demeter LM, Courier JS, Eron Jr JJ, Feinberg JE, Balfour Jr HH, Deyton LR, Chodakewwitz JA, Fischl MA. A controlled trial of two nucleoside analogues plus indinavir in persons with human immunodeficiency virus infection and CD4 cell counts of 200 per cubic millimeter or less. AIDS Clinical Trials Group 320 Study Team. New England Journal of Medicine 337:725-733, 1997.

6. Knodell RG, Ishak KG, Black WC, Chen TS, Craiq R, Kaplowitz N, Kierman TW, Wollman J. Formulation and application of a numerical scoring system for assessing histological activity in asymptomatic chronic active hepatitis. Hepatology 1:431-435, 1981.

7. Kowdley KV. Hematologic side effects of interferon and ribavirin therapy. Journal of Clinical Gastroenterology 39(suppl I):S3-S8, 2005.

8. Moccia F, Tognoni E, Boccaccio P. Autoimmune hemolytic anemia in chronic hepatitis C virus infection: an unusual extrahepatic autoimmune manifestation. Annali Italiani di Medicina Interna 16:256-259, 2001.

9. Saif MW. HIV-associated autoimmune hemolytic anemia: an update. AIDS Patient Care and STDs 15:217-224, 2001

10. Serna-Higuera C, Barcena-Marugan R, Sanz-de-Villalobos E. Hemolytic anemia secondary to alpha-interferon treatment in a patient with chronic $\mathrm{C}$ hepatitis. Journal of Clinical Gastroenterology 28:358-359, 1999.

11. Soriano V, Sulkowski M, Bergin C, Hatzakis A, Cacoub P, Katlama C, Cargnel A, Mauss S, Dieterich D, Moreno S, Ferrari C, Poynard C, Rockstroh J. Care of patients with chronic hepatitis $\mathrm{C}$ and HIV co-infection: recommendations from the HIV-HCV International Panel. AIDS 16:813-828, 2002.

12. Torriani FJ, Rodriguez-Torres M, Rockstroh JK, Lissen E, Gonzales-Garcia J, Lazzarin A, Carosi G, Sasadeusz J, Katlama C, Montaner J, Sette H, Passe S, De Pamphilis J, Duff F, Schrenk UM, Dieterich D, Apricot Study Group. Peginterferon Alfa-2a plus ribavirin for chronic hepatitis $\mathrm{C}$ virus infection in HIV-infected patients. New England Journal of Medicine 351:438-450, 2004. 